\title{
Perspectives
}

\section{Semantic Prosody and ESL/EFL Vocabulary Pedagogy}

There is evidence that semantic prosody, a novel linguistic theme, should attract much attention in ESL/EFL (English as a second/foreign language) vocabulary learning and teaching. Research suggests that inappropriate word choice arising from ignorance of semantic prosody is common among ESL/EFL learners (Wei, 2006; Xiao \& McEnery, 2006). This article introduces the notion of semantic prosody and provides an overview of studies of semantic prosody from five perspectives: monolinguistic, cross-linguistic, register, lexicographical, and interlinguistic. Based on this overview, the article suggests that semantic prosody be integrated into ESL/EFL vocabulary pedagogy. Finally, implications on integrating semantic prosody into ESL/EFL vocabulary pedagogy are discussed.

Certaines sources indiquent que la prosodie sémantique, un nouveau thème linguistique, méritrait que les intervenants en enseignement $d u$ vocabulaire en ALS/ALE (anglais langue seconde/étrangère) y portent attention. La recherche porte à conclure que le choix de mots inapproprié découlant de l'ignorance de la prosodie sémantique est un phénomène commun chez les apprenants en ALS/ALE (Wei, 2006; Xiao \& McEnery, 2006). Cet article présente la notion de la prosodie sémantique et fournit un aperçu, à partir de cinq perspectives, des études portant sur la prosodie sémantique: monolinguistique, portant sur plus d'une langue, basée sur le registre, lexicographique et interlinguistique. À partir de cette vue d'ensemble, l'auteur propose que la prosodie sémantique soit intégrée à la pédagogie du vocabulaire en ALS/ALE. L'article termine par une discussion des répercussions de cette intégration.

\section{Introduction}

The notion of semantic prosody arising from corpus linguistics and reflecting the realization that lexical items are habitually associated with particular connotations (Louw, 1993; Siepmann, 2005; Sinclair, 1991; Stubbs, 1995) has attracted considerable attention since its advent in the early 1990s. With the help of computerized corpora data, much research has examined this linguistic phenomenon from various perspectives. Along with this line of research, researchers also have recognized the importance and necessity of semantic prosody for ESL/EFL (English as a second/foreign language) vocabulary 
learning and teaching (Hoey, 2000; Partington, 1998; Zethsen, 2006). The purpose of this article is twofold: (a) to introduce the notion of semantic prosody and provide an overview of corpus-based studies of semantic prosody; and (b) to help develop ESL/EFL educators' awareness that semantic prosody needs to be integrated into vocabulary pedagogy.

\section{Defining Semantic Prosody}

The term semantic prosody, also called semantic harmony (LewandowskaTomaszczyk, 1996), discourse or pragmatic prosody (Stubbs, 2001), or semantic associations (Hoey, 2003; Nelson, 2006), was coined by Sinclair (1987), who borrowed Firth's (1957) notion of phonological prosody. Semantic prosody was first introduced to the public by Louw (1993). This term has been widely used by Hunston (2002, 2007), Partington (1998, 2004), Stubbs (1995, 2001), Tognini-Bonelli (2001), and Tribble (2000), among many others. Currently semantic prosody has become an important concept in corpus linguistics (Whitsitt, 2005).

For this concept, definitions have been provided by various researchers, for example, Sinclair (1987, 1991), Louw (1993, 2000), Stubbs (1995), Tribble (2000), and Hunston (2002). Sinclair (1991), although not explicitly using the term semantic prosody, first described the phenomenon that "many uses of words and phrases show a tendency to occur in a certain semantic environ-

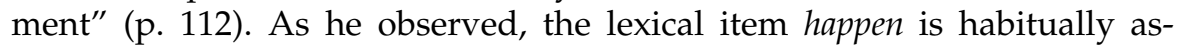
sociated with unpleasant events (e.g., Accidents happen). Similarly, Louw (1993), directly employing the term semantic prosody, perceived it as "a consistent aura of meaning with which a form is imbued by its collocates" (p. 157). In Louw's view, semantic prosody cannot be retrieved reliably through introspection, and consciously upsetting a word's semantic prosody can achieve an ironic effect. Louw (2000) further claimed that negative semantic prosodies were much more frequent than positive ones. Another researcher, Partington (1998), defined semantic prosody as "the spreading of connotational coloring beyond single word boundaries" (p. 68). In this definition, semantic prosody is more strongly associated with connotation. Stubbs (1995) and Hunston (2002) expanded the notion of semantic prosody by suggesting that in addition to collocating with positive or negative groupings of words, lexical items can also collocate with semantic sets. According to Hunston, "A word may be said to have a particular semantic prosody if it can be shown to co-occur typically with other words that belong to a particular semantic set" (p. 104). For example, the word unemployment displays a tendency to collocate with the semantic set of statistics. Tribble's definition further broadened the notion of semantic prosody in that a lexical item can be featured with both a global semantic prosody in terms of the whole language, and a local semantic prosody in a certain context or genre. His analysis of the word experience in a genre-based corpus showed that there is a local semantic 
prosody of experience in the genre examined. In view of the above definitions of semantic prosody, it seems that they are basically the same except for differences in scope. For a better understanding of semantic prosody, its primary features are summarized below. First, semantic prosody mainly functions to express speakers'/writers' attitude and evaluation (Louw, 2000). Mostly, semantic prosody is realized in the form of positive (or favorable), neutral, and negative (or unfavorable) connotations (Stubbs, 1995). For example, the English adjective impressive tends to co-occur with lexical items such as dignity, talent, best, gains, and achievement. Impressive can thus be considered to have a positive semantic prosody. The word rife, however, often collocates with lexical items such as crime, diseases, misery, corruption, and speculation (Partington): rife is thus considered to have a negative semantic prosody.

Semantic prosody can also be extended to include other qualities such as unexpectedness (Louw, 1993; Tao, 2003). Specifically, semantic prosody is used to convey irony, insincerity, or humor "if a collocation is chosen which is at odds with the usual semantic set" (Hunston \& Francis, 2000, p. 105). As Louw argues, when writers/speakers consciously diverge from normal collocational patterns, ironic intent will be achieved, as shown in the following discourse:

The modern conference resembles the pilgrimage of medieval

Christendom in that it allows the participants to indulge themselves in

all the pleasures and diversions of travel while appearing to be

austerely bent on self-improvement. (p. 164)

In this sentence, the use of bent on self-improvement develops an ironic intention because of the semantic prosodic clash between bent on (which generally has a negative prosody) and self-improvement (which has a positive prosody).

Moreover, in most cases, semantic prosody is beyond the reach of human intuition about language (Channell, 2000; Louw, 1993; Marcinkeviciene, 2000). In other words, semantic prosody does not belong to speakers' conscious knowledge of a language. Only through interpreting large numbers of instances of a word or phrase can we observe semantic prosody. The advent of different corpora thus makes it possible for researchers to extract profiles of semantic prosodies.

Another characteristic of semantic prosody is that it can be associated with grammatical principles. For example, as Louw (1993) observed, build up tends to reveal a positive semantic prosody when it is used transitively (e.g., build up confidence). Used intransitively, however, build up shows a negative prosody (e.g., resistance builds up).

Finally, not only an individual word but also a phrase or a clause may have a semantic prosody. For example, the fixed phrase par for the course, which is used to indicate that something is normal or usual, has a negative 
semantic prosody as shown in the sentence "Delays at airports in the holiday season are par for the course."

\section{Corpus-Based Studies of Semantic Prosody}

The literature shows that considerable corpus-based research has explored the notion of semantic prosody mainly from five perspectives: monolinguistic, cross-linguistic, register, lexicographical, and interlinguistic.

\section{Monolinguistic English Studies}

In recent years extensive corpus-based research has been conducted on semantic prosodies of lexical items in the English language. Table 1 provides a summary of these studies. Sinclair's (1991) investigation of the semantic prosody of the phrase set in showed that this phrase is characterized by a negative connotation because it tends to be associated with unpleasant events. The words that set in usually collocates with are rot, decay, ill-will, decadence, infection, and prejudice. Similarly, Louw's (1993) study indicates that the semantic prosody of utterly has a negative connotation. If positive

Table 1

Semantic Prosodies of Some English Lexical Items

\begin{tabular}{|c|c|c|c|}
\hline \multirow[t]{2}{*}{ Researcher } & \multicolumn{3}{|c|}{ Semantic Prosody } \\
\hline & Negative & Positive & Neutral \\
\hline Channell (2000) & $\begin{array}{l}\text { par for the course } \\
\text { roam the streets }\end{array}$ & & \\
\hline Hunston (2002) & sit through & & \\
\hline Louw (1993) & $\begin{array}{l}\text { bent on } \\
\text { build up (intransitive) } \\
\text { utterly } \\
\text { symptomatic of }\end{array}$ & build up (transitive) & \\
\hline Partington (1998) & $\begin{array}{l}\text { commit } \\
\text { peddle } \\
\text { dealings }\end{array}$ & & \\
\hline Sinclair $(1987,1991)$ & $\begin{array}{l}\text { break out } \\
\text { happen } \\
\text { set in }\end{array}$ & & \\
\hline Stubbs (1995) & $\begin{array}{l}\text { break out } \\
\text { cause } \\
\text { effects } \\
\text { happen }\end{array}$ & $\begin{array}{l}\text { reason } \\
\text { provide }\end{array}$ & $\begin{array}{l}\text { create } \\
\text { effect }\end{array}$ \\
\hline Wei (2002) & $\begin{array}{l}\text { cause } \\
\text { incur } \\
\text { utterly }\end{array}$ & career & probability \\
\hline
\end{tabular}


instead of negative collocates occur with utterly, the forms carry an ironic intention.

Stubbs (1995) analyzed the semantic prosody of the word cause (verb and noun). His finding was that more than $90 \%$ of its collocates are negative (e.g., cancer, crisis, accident, delay, death, damage, trouble). Stubbs also observed that the word effects (in its plural form) is usually featured with a negative semantic prosody. Its collocates usually include adverse, devastating, harmful, ill, negative, and toxic. Partington (1998) found that the verb commit, which tends to collocate with words like crime, offences, and foul, has a negative semantic prosody. Channell (2000) investigated the phrase roam the streets. Her study indicated that the semantic prosody of roam the streets tends to have a negative connotation because its collocates usually are the words looters, vagrant children, and prostitutes.

\section{Cross-Linguistic Studies}

Researchers have also examined semantic prosodies cross-linguistically (Sardinha, 2000; Tognini-Bonelli, 2001; Xiao \& McEnery, 2006). Sardinha conducted a cross-linguistic examination of semantic prosodies of English and Portuguese. Tognini-Bonelli compared English and Italian semantic prosodies. Xiao and McEnery's study explored semantic prosodies of near synonyms (referring to lexical pairs having similar cognitive or denotational meanings, but perhaps differing in collocational or prosodic behavior, for example, result, outcome, consequence, and aftermath) in English and Chinese.

Although some studies show that semantic prosody may vary across languages, for example, as Sardinha (2000) observed, there are no direct equivalents for the English verb phrase set in in Portuguese: cross-linguistic studies mostly indicate that semantic prosody seems to be universal across languages. According to Sardina, the English verb commit and its translation equivalent cometer in Portuguese display similar features of semantic prosody, both having a negative connotation. And in their study of near synonyms in the consequence group (i.e., result, outcome, consequence, aftermath) in the English language and their translation equivalents in the Chinese language, Xiao and McEnery (2006) observed that the four near synonyms of outcome/result, consequence, and aftermath could be arranged on a semantic continuum from positive to negative. The Chinese translation equivalents of these words also display this continuum pattern.

Register Studies of Semantic Prosody

Besides a global semantic prosody in general English, a lexical item can also have a local semantic prosody that occurs only in certain registers (Nelson, 2006; Tribble, 2000). Researchers thus have tried to explore semantic prosody in various registers (Baker \& McEnery, 2004; Cao, 2006; Fuentes, 2001; Lam, 
2007; Nelson, 2000, 2006; Wei, 2002). Focusing on business English corpora, for example, Nelson's work showed that collocates tend to become more fixed in business English than in general English. The word manage, for example, is mainly business-related in business English. In general English, however, manage has a wider collocative potential. Nelson also observed that even when a word has the same semantic prosody in both business English and general English, there may be a difference in the size and content of the prosodic groups. In the case of send, for example, the documents sent in business English are mainly business-related whereas the documents sent in general English are more varied and general (e.g., non-business letters, postcards, and packages). Take package as another example. In business English, package occurs with three groups of collocates, the largest of which is financially related (18.51\% of the sample in business English). In general English, however, this group is much smaller (5.33\% of the sample). In addition, the positive semantic prosody of package found in business English (e.g., competitive package, excellent package, effective package) is not evident in general English.

Wei's (2002) study of semantic prosody involved a corpus of academic English texts. His analysis of the lexical item cause revealed that cause has a negative semantic prosody, matching the finding of such other researchers as Stubbs (1995) with respect to general English. However, he also found that cause shows a stronger negative prosody in academic English texts than in general English texts. Wei further observed that the word career has a positive semantic prosody in both academic English texts and general English texts, but that career in academic English texts differs from its counterpart in general English texts in that career shows a weaker positive semantic prosody in academic English texts. Wei thus argued that semantic prosody exists with its own features in specialized texts.

\section{Lexicographical Studies}

Researchers have studied the situation of semantic prosodic representation in dictionaries. Regarding English-English dictionaries, Partington (1998) examined the semantic prosodies of set in, peddle, and dealings. He found that corpus-based English monolinguistic dictionaries provide more accurate semantic prosodic information than those dictionaries not based on corpus data. Pan and Feng's (2003) study of the word rife in English-English dictionaries also indicated that Webster's Dictionary of the English Language (Unabridged) (1979), which defines rife as "1. prevalent; frequently or commonly occurring; current. 2. abundant; plentiful. 3. filled; abounding; followed by/with"-does not present the negative semantic prosody of rife. The corpus-based English monolinguistic dictionaries, for example, Collins COBUILD English Language Dictionary (1987) and Longman Dictionary of Contemporary English (1995), include the appropriate semantic prosodic feature 
of rife. Pan and Feng thus concluded that semantic prosody is becoming increasingly important in dictionary construction with the advent of various computerized corpora.

Research has also been conducted on how semantic prosody is treated in bilingual dictionaries. Ji and $\mathrm{Wu}(2000)$ examined the semantic prosodies of set in, rife, and propaganda in three modern English-Chinese dictionaries. Earlier studies (Sinclair, 1991) had shown that these three lexical items tend to have negative prosodies. However, Ji and $\mathrm{Wu}$ observed that none of the bilingual dictionaries that they examined presented the negative semantic prosody of the phrase set in. As regards rife and propaganda, the three bilingual dictionaries even provide wrong information about their semantic prosodies, thus misguiding dictionary users. The word rife, for example, whose Chinese translation equivalents should be chong1chi4 or fan4lan4, with a negative prosody, is translated as sheng4xing2, pu3bian4, fu4yu2, or chong1man3, mostly with positive prosodies.

Wang (2004) studied the semantic prosodies of five lexical items (i.e., incite, impressive, contribute to, and a pair of near synonyms persist and persevere) in 10 English-Chinese bilingual dictionaries widely used in China. He first analyzed the semantic prosodies of these lexical items in English native speakers' corpora and then examined their semantic prosodies as presented in the dictionaries. His analyses showed that incite and persist tend to have negative semantic prosodies, contribute to has a neutral prosody, and the other two words impressive and persevere have positive prosodies. Based on his observations and analyses, he concluded that the positive semantic prosodies of lexical items are properly represented through translation equivalents, examples, and usage notes in the dictionaries (e.g., those of impressive and persevere), but the negative semantic prosodies of the lexical items are not appropriately represented in terms of the translation equivalents and examples provided (e.g., incite, persist). For example, despite the negative semantic prosody of incite, most of the bilingual dictionaries present a positive prosody for incite through its translation equivalents ji1li4 and jilfa1 and examples with Chinese translation provided in the dictionaries:
incite the soldiers to fight bravely
jilli4 shi4bing1 yong2gan3 zuo4zhan4
incite somebody's curiosity
jilfa1 mou3ren 2 de hao4qi2xin1

Thus Wang suggested that for bilingual dictionary writers, "an entry should pick out typical features and offer sound examples" (p. 40) in order to avoid misleading ESL/EFL language learners. All the studies discussed above may suggest that semantic prosody should be included in dictionaries to help learners use words appropriately (Ji \& Wu, 2000; Pan \& Feng, 2003; Wang). 


\section{Interlinguistic Studies}

In the past decade, researchers and educators have devoted much effort to exploring the issue of semantic prosody in ESL/EFL learners' interlanguage (Lu, 2005; Siepmann, 2005; Wang \& Wang, 2005; Wei, 2006). Siepmann's research, for example, indicated that German speakers of English are prone to pragmatic errors due to a misunderstanding of the semantic prosodies of lexical items (e.g., the idiom have s.th. at one's fingertips and the verb phrase stand for). Lu's contrastive study, based on native English speakers' corpora and Chinese EFL learner corpora, examined the semantic prosodic features of the seemingly synonymous words gain and obtain. She observed that in English native speakers' production, gain has a strong positive semantic prosody and obtain shows a neutral semantic prosody. In Chinese EFL learners' production, however, gain and obtain are both featured with a strong positive semantic prosody and are used identically.

In another study, Wang and Wang (2005) focused on the semantic prosody of the lexical item cause in Chinese EFL learners' interlanguage and native English speakers' language. Their findings revealed that there are significant differences in the semantic prosody of cause between English native speakers and Chinese EFL learners. For native English speakers, cause tends to have a negative semantic prosody. Chinese EFL learners in the study, however, underused the negative semantic prosody of cause but overused its atypical positive semantic prosody. The following are some examples of Chinese EFL learners' misuse of the semantic prosody of the word cause.

1. The other cause is the change of medical condition. The doctors now can cure many diseases which was incurable in the past.

2. The most important reason which caused these changes was the development of economy in developing countries.

3. ... infant mortality was 100 deaths per 10000 births in developing countries of the world. What caused these great changes? (Wang \& Wang, 2005, pp. 300-304)

Wei's (2006) corpus-based study further confirmed Wang and Wang's finding that Chinese EFL learners' use of cause tends to be with a positive semantic prosody. His findings showed that Chinese learners often collocate cause with words like development, progress, and improvement. Wei further argued that native speakers' conscious use of unusual collocations with a lexical item is generally for a special communicative effect (e.g., to develop an ironic intention), whereas non-native speakers' use usually reflects pragmatic errors. These interlinguistic studies may suggest that inappropriate word choice arising from ignorance of semantic prosody is not uncommon in ESL/EFL learners. 


\section{Implications for ESL/EFL Vocabulary Pedagogy}

Vocabulary has been widely recognized as central to second language (L2) learning (Laufer, 1997; Sökmen, 1997). Knowing a word mainly involves knowing how to use the word syntactically, semantically, and pragmatically (Carter, 1998; McKay, 1980). For L2 learners and teachers, a big challenge in learning a word lies in mastering its pragmatic function (Zhang, 2008), which is related to its semantic prosody (Partington, 1998; Sinclair, 1996). The interlinguistic studies reviewed above indicate that $\mathrm{L} 2$ learners tend to make errors associated with semantic prosody. Tsui's (2005) research also indicates that for ESL teachers, one challenge in vocabulary instruction concerns the semantic prosodies of synonyms or near-synonyms. For ESL/EFL vocabulary teaching and learning, therefore, corpus-based studies of semantic prosody may have at least three implications.

First, based on semantic prosody studies, researchers have realized the significance of semantic prosody in ESL/EFL learning and teaching (Hoey, 2000; Nesselhauf, 2003; Partington, 1998; Xiao \& McEnery, 2006). As Partington argued, information about semantic prosody is "vital for non-native speakers to understand not only what is grammatically possible in their language production but ... also what is appropriate and what actually happens" (p. 8). Awareness of semantic prosody not only can be greatly beneficial in interpreting a text producer's hidden attitudes, but can also help language learners understand how to use lexical items appropriately. For vocabulary learning, therefore, ESL/EFL learners need to master not only a lexical item's spelling, meanings, and grammatical features, but also its semantic prosody. Without a command of its semantic prosody, learners may have difficulty in using a given lexical item for effective communication (Xiao \& McEnery).

Second, semantic prosody should be integrated into ESL/EFL vocabulary teaching to help develop language learners' communicative competence. As Xiao and McEnery (2006) argued, ESL/EFL learners' intuition of the target language-different from that of native speakers-is typically less reliable and thus cannot help such learners detect the usage of a lexical item in terms of its semantic prosody. Interlinguistic studies of semantic prosody also indicate that ESL/EFL learners, when learning a lexical item, seldom notice its semantic prosody and often make semantic prosodic errors in communication for the following two reasons (Wang \& Wang, 2005; Wei, 2006).

1. ESL/EFL instructors may be unaware of the importance of semantic prosody and underestimate it in teaching. In vocabulary teaching, they generally focus more attention on the denotational meanings of a lexical item without recognizing the function of its semantic prosody in language communication. 
2. ESL/EFL textbooks or bilingual dictionaries do not explicitly represent the feature of semantic prosody or may provide inappropriate semantic prosodic information that can mislead language learners.

Therefore, "vocabulary teaching needs to take account of semantic prosody" (Hunston, 2002, p. 142). For this purpose, the preliminary step may be to educate ESL/EFL teachers, helping them understand the notion of semantic prosody, and then consider how to involve semantic prosody in vocabulary instruction. Moreover, bilingual lexicographers need to make semantic prosodic information explicit for ESL/EFL learners, particularly for beginning and intermediate learners who prefer to use bilingual dictionaries. For ESL/EFL textbook writers, textbook glossaries also need to present appropriate semantic prosodies of lexical items. As has been widely recognized, textbooks play an important role in shaping language use by ESL/EFL learners whose exposure to the target language is limited (Lee, 2006). ESL/EFL learners often use the glossaries in textbooks to enlarge vocabulary.

Finally, although researchers have recognized the significance of semantic prosody in language communication (Partington, 1998; Xiao \& McEnery, 2006), little work has been done to explore how to apply semantic prosody in ESL/EFL pedagogy. Practical and empirical research, therefore, will be needed with respect to how semantic prosody may be effectively integrated into ESL/EFL vocabulary teaching and learning.

\section{The Author}

Weimin Zhang is an associate professor of applied linguistics at Tsinghua University, Beijing. He has taught EFL in China and ESL in the United States for 16 years. He holds an MA in English language teaching from the University of Nottingham, UK and a doctorate in applied linguistics from Georgia State University, USA. His research interests include corpus linguistics and L2 pedagogy, L2 teacher education, language attitudes and sociolinguistics, and genre theory and L2 writing.

\section{References}

Baker, P., \& McEnery, T. (2004). A corpus-based approach to discourses of refugees in UN and newspaper texts. Retrieved July 1, 2007, from:

http://www.kcl.ac.uk/humanities/cch/ake/final/redist/pdf/baker_mcenery.pdf

Cao, Y. (2006). A contrastive study of the semantic prosody and colligation in two news corpora. Unpublished master's thesis, Dalian Maritime University, Dalian, China.

Carter, R. (1998). Vocabulary: Applied linguistic perspectives (2nd ed.). London: Routledge.

Channell, J. (2000). Corpus-based analysis of evaluative lexis. In S. Hunston \& G. Thompson (Eds.), Evaluation in text: Authorial stance and the construction of discourse (pp. 39-55). Oxford, UK: Oxford University Press.

Firth, J. (1957). Papers in linguistics, 1934-1951. London: Oxford University Press.

Fuentes, A.C. (2001). Lexical behavior in academic and technical corpora: Implications for ESP development. Language Learning and Technology, 5(3), 106-129.

Hoey, M. (2000). A world beyond collocation: New perspectives on vocabulary teaching. In M. Lewis (Ed.), Teaching collocations: Further developments in the lexical approac. (pp. 224-245). Hove, UK: Language Teaching. 
Hoey, M. (2003). Lexical priming and the qualities of text. Retrieved October 14, 2008, from: http://www.monabaker.com/tsresources/LexicalPrimingandthePropertiesofText.htm

Hunston, S. (2002). Corpora in applied linguistics. Cambridge, UK: Cambridge University Press.

Hunston, S. (2007). Semantic prosody revisited. International Journal of Corpus Linguistics, 12(2), 249-268.

Hunston, S., \& Francis, G. (2000). Pattern grammar: A corpus-driven approach to the lexical grammar of English. Philadelphia, PA: John Benjamins.

Ji, Y., \& Wu, J. (2000). Research into semantic prosody: Targets, methodology and application. Journal of Xiamen University (Arts and Social Sciences), 143, 63-68.

Lam, P.Y.W. (2007). A corpus-driven lexico-grammatical analysis of English tourism industry texts and the study of its pedagogic implications in English for Specific Purposes. In E. Hidalgo, L. Quereda, \& J. Santana (Eds.), Corpora in the foreign language classroom (pp. 71-89). Amsterdam: Rodopi.

Laufer, B. (1997). What's in a word that makes it hard or easy: Some intralexical factors that affect the learning of words. In N. Schmitt \& M. McCarthy (Eds.), Vocabulary, description, acquisition and pedagogy (pp. 140-155). Cambridge, UK: Cambridge University Press.

Lee, J. (2006). Subjunctive were and indicative was: A corpus analysis for English language teachers and textbook writers. Language Teaching Research, 10(1), 80-93.

Lewandowska-Tomaszczyk, B. (1996). Cross-linguistic and language-specific aspects of semantic prosody. Language Sciences, 18, 153-178.

Louw, B. (1993). Irony in the text or insincerity in the writer? The diagnostic potential of semantic prosodies. In M. Baker, G. Francis, \& E. Tognini-Bonelli (Eds.), Text and technology: In honour of John Sinclair (pp. 157-176). Amsterdam: John Benjamins.

Louw, B. 2000). Contextual prosodic theory: Bringing semantic prosodies to life. In C. Heffer, H. Sauntson, \& G. Fox (Eds.), Words in context: A tribute to John Sinclair on his retirement (pp. 48-94). Birmingham, UK: University of Birmingham.

$\mathrm{Lu}, \mathrm{L}$. (2005). How corpus-based approach can contribute to the study of seemingly synonymous words. CELEA Journal, 28(6), 14-20.

Marcinkeviciene, R. (2000). The pattern of word usage viewed by corpus linguistics. Kalbotyra, 49(3), 71-80.

McKay, S. (1980) Teaching the syntactic, semantic and pragmatic dimensions of verbs. TESOL Quarterly, 14, 17-26.

Nelson, M. (2000). A corpus-based study of business English and business English teaching materials. Unpublished doctoral dissertation, University of Manchester.

Nelson, M. (2006). Semantic associations in Business English: A corpus-based analysis. English for Specific Purposes, 25, 217-234.

Nesselhauf, N. (2003). The use of collocations by advanced learners of English and some implications for teaching. Applied Linguistics, 24(2), 223-242.

Pan, P., \& Feng, Y. (2003). Corpus-based analysis of semantic prosody and its applications. Contemporary Linguistics, 5(4), 359-366.

Partington, A. (1998). Patterns and meanings: Using corpora for English language research and teaching. Philadelphia, PA: John Benjamins.

Partington, A. (2004). "Utterly content in each other's company": Semantic prosody and semantic preference. International Journal of Corpus Linguistics, 9(1), 131-156.

Sardinha, T.B. (2000). Semantic prosodies in English and Portuguese: A contrastive study. Cuadernos de Filologia Inglesa, 9(1), 93-110.

Siepmann, D. (2005). Discourse markers across languages: A contrastive study of second-level discourse markers in native and non-native text with implications for general and pedagogic lexicography. London: Routledge.

Sinclair, J. (1987). Looking up: An account of the COBUILD project in lexical computing and the development of the Collins COBUILD English language dictionary. London/Glasgow: Collins.

Sinclair, J. (1991). Corpus, concordance, collocation. Oxford, UK: Oxford University Press. 
Sinclair, J. (1996). The search for units of meaning. TEXTUS: English Studies in Italy, 9(1), 75-106. Sökmen, A. (1997). Current trends in teaching second language vocabulary. In N. Schmitt \& M. McCarthy (Eds.), Vocabulary: Description, acquisition, and pedagogy (pp. 237-257). Cambridge, UK: Cambridge University Press.

Stubbs, M. (1995). Collocations and semantic profiles: On the cause of trouble with quantitative studies. Functions of Language, 2(1), 23-55.

Stubbs, M. (2001). Words and phrases: Corpus studies of lexical semantics. New York: Blackwell.

Tao, H. (2003). Toward an emergent view of lexical semantics. Language and Linguistics, 4, 837-856.

Tognini-Bonelli, E. (2001). Corpus linguistics at work. Amsterdam: John Benjamins.

Tribble, C. (2000). Genres, keywords, teaching: Towards a pedagogic account of the language of project proposals. In L. Burnard \& T. McEnery, (Eds.), Rethinking language pedagogy from a corpus perspective: Papers from the Third International Conference on Teaching and Language Corpora (pp. 74-90). New York: Peter Lang.

Tsui, A.B.M. (2005). ESL teachers' questions and corpus evidence. International Journal of Corpus Linguistics, 10(3), 335-356.

Wang, H., \& Wang, T. (2005). A contrastive study on the semantic prosody of CAUSE. Modern Foreign Language, 28(3), 297-307.

Wang, Q. (2004). A corpus-based study of semantic prosodies and bilingual dictionaries. Unpublished master's thesis, Suzhou University, China.

Wei, N.X. (2002). A corpus-driven study of semantic prosodies in specialized texts. Modern Foreign Language, 25(2), 165-175.

Wei, N.X. (2006). A corpus-based contrastive study of semantic prosodies in learner English. Foreign Language Research, 132, 50-54.

Whitsitt, S. (2005). A critique of the concept of semantic prosody. International Journal of Corpus Linguistics, 10(3), 283-305.

Xiao, Z., \& McEnery, A. (2006). Collocation, semantic prosody and near synonymy: A cross-linguistic perspective. Applied Linguistics, 27(1), 103-129.

Zethsen, K.K. (2006). Semantic prosody: Creating awareness about a versatile tool. Tidsskrift for Sprogforskning, 4(1), 275-294.

Zhang, W. (2008). In search of English as foreign language (EFL) teachers' knowledge of vocabulary instruction. Unpublished doctoral dissertation, Georgia State University. 